\title{
Faktor-faktor yang Mempengaruhi Kematian Pasien Penyakit Jantung Koroner di Pusat Jantung Nasional Harapan Kita Tahun 2004
}

\author{
Fatmah A. Gobel* Renti Mahkota**
}

\begin{abstract}
Abstrak
Menurut estimasi WHO, sekitar 50\% dari 12 juta penduduk dunia meninggal akibat penyakit jantung dan pembuluh darah. Faktor prognosis pasien PJK dapat diubah dan dikendalikan, dan memungkinkan untuk mencegah kematian akibat PJK. Penelitian ini bertujuan mengetahui faktor prognosis yang berhubungan dengan terjadinya kematian pasien PJK di PJN Harapan Kita Tahun 2004, menggunakan data sekunder (data rekam medik pasien). Variabel-variabel yang diteliti meliputi variabel independen (jaminan pembayaran, asal daerah/kawasan, penyakit penyerta hipertensi, diabetes melitus, dislipidemia dan riwayat PJK sebelumnya) dan variabel kovariat (umur, jenis kelamin, pendidikan dan pekerjaan). Desain epidemiologi yang digunakan adalah analitik kasus kontrol dengan jumlah kasus 130, kontrol 260 (1:2). Kasus adalah pasien PJK yang meninggal dibuktikan dengan ringkasan pasien meninggal, kontrol adalah pasien yang keluar hidup. Data di analisis multivariat. Hasil penelitian, jaminan pembayaran dan asal daerah/kawasan berhubungan dengan terjadinya kematian pasien. Pasien dengan pembayaran pribadi dan yang berasal dari Jawa berisiko lebih tinggi untuk meninggal daripada pasien dengan jaminan pembayaran Askes dan yang berasal dari luar Jawa. Masyarakat disarankan menjadi peserta asuransi kesehatan atau jaminan pemeliharaan kesehatan lain. Penelitian lain perlu mempertimbangkan keganasan penyakit sehingga hubungan antara faktor prognosis dan kematian dapat lebih jelas untuk setiap tahap penyakit.

Kata kunci: Prognosis, penyakit jantung koroner, logistik regresi
\end{abstract}

\begin{abstract}
According to WHO estimate, about $50 \%$ people died each year on the world caused by heart and arterial diseases. There are many prognostic factors of heart diseases that could be changed and controlled; therefore this disease is preventable regarding the mortality. This study aimed to understand prognostic factors related to mortality among coronary heart disease. The source of data is secondary data patient medical record at Harapan Kita National Heart Centre in 2004. The independent variables were health insurance, place of origin, hypertension, diabetes mellitus, dislipidemia, and previous history of $\mathrm{CHD}$ while covariate variables were age, gender, education, and occupation. The study design is case-control study with 130 cases and 260 controls (1:2). Cases were death CHD patients confirmed by death summary record, controls were survivor patients. Data were analyzed in multivariate ways. The study results shows that health insurance and place of origin were associated to patient's mortality. Patients without insurance have higher risk to die then patients with Askes health insurance. Patients came from Java island have higher risk to die then those who came from outside Java. Public is recommended to be member of health insurance. Other research need to be conducted by considering the severity of the diseases and therefore the relationship between prognostic factors and outcome could be clearer for each stage of disease.
\end{abstract}

Keywords: Prognostic, coronary heart disease, logistic regression

*Staf Pengajar Fakultas Kesehatan Masyarakat Universitas Muslim Indonesia, **Staf Pengajar Departemen Epidemiologi Fakultas Kesehatan Masyarakat Universitas Indonesia 
Diseluruh dunia, penyakit jantung koroner (PJK) merupakan kausa utama kematian. Menurut estimasi para ahli badan kesehatan sedunia (WHO), setiap tahun sekitar $50 \%$ penduduk dunia meninggal akibat penyakit jantung dan pembuluh darah. Di Eropa dan Asia menurut World Health Report 1997, tercatat 15 juta orang meninggal akibat penyakit jantung koroner atau sama dengan 30\% dari total kematian di seluruh dunia. Di Amerika pada tahun 1990 penyakit jantung koroner menyebabkan 916.000 kematian, atau merupakan 43\% penyebab kematian di negara tersebut. Di Inggris penyakit jantung koroner telah menyebabkan lebih dari 180.000 kematian setiap tahun. ${ }^{1}$ Di Indonesia, pada tahun 1992-2000 proporsi kematian penyakit jantung dan pembuluh darah mengalami peningkatan cukup tajam. Berdasarkan data Survei Kesehatan Rumah Tangga (SKRT) pada tahun 1992, angka kematian PJK sekitar $16,4 \%$ dan terus mengalami peningkatan dari tahun ke tahun. Pada 1995 sampai 2001 angka kematian tersebut meningkat dari $24,5 \%$ menjadi $26,4 \% .^{2}$

Kematian akibat penyakit jantung koroner berhubungan dengan berbagai faktor, meliputi: (1) Proxi yang terdiri dari: jenis kelamin, pendidikan, jaminan pembayaran, obesitas, merokok, asal daerah/ kawasan dan riwayat keluarga; (2) Intermediate yang terdiri dari: umur, asupan asam lemak omega 3, tindakan, riwayat PJK sebelumnya, waktu pasien ditangani, jenis angina, karakteristik jantung dan arteri koroner, iskemia, Infark Miokard Akut, dan penyakit penyerta (terdiri dari: hipertensi, diabetes mellitus, \& dislipidemia); (3) Immediate yang terdiri dari: komplikasi yang antara lain: perikarditis, embolisme paru, syok kardiogenik, oedema paru akut, aritmia jantung, ruptur jantung (termasuk ruptur septum, ruptur muskulus papilaris dan ruptur eksterna jantung). Berbagai faktor tersebut banyak yang dapat dirubah dan dikendalikan, sehingga memungkinkan untuk mencegah kematian akibat penyakit jantung koroner. Oleh sebab itu, perlu dilakukan penelitian tentang faktor-faktor prognosis yang berhubungan dengan kematian pasien penyakit jantung koroner.

Pusat Jantung Nasional Harapan Kita merupakan pusat penanggulangan penyakit jantung nasional dan menjadi pusat rujukan dari berbagai rumah sakit di seluruh Indonesia. Pasien yang datang berobat berasal dari berbagai wilayah (kawasan dan daerah) di seluruh Indonesia. Selain itu, rumah sakit tersebut merupakan rumah sakit pendidikan dan pusat penelitian jantung nasional, sehingga memungkinkan memperoleh data yang lengkap dan memadai untuk melaksanakan penelitian, itulah sebabnya penelitian tentang faktorfaktor yang berhubungan dengan kematian pasien penyakit jantung koroner ini kami lakukan di rumah sakit ini. Penyakit jantung koroner merupakan penyakit tidak menular yang dapat dicegah dan cara terbaik untuk menurunkan kematian tersebut adalah dengan mengetahui berbagai faktor prognosis yang berhubungan dengan kematian pasien PJK.

\section{Metode}

Penelitian ini menggunakan desain studi epidemiologi kasus kontrol dengan menggunakan sumber data sekunder rekam medik pasien Pusat Jantung Nasional Harapan Kita pada periode Januari - Desember 2004. Populasi studi adalah penderita penyakit jantung koroner yang ditentukan berdasarkan diagnosis dokter spesialis penyakit jantung yang merawat dan tercatat dalam rekam medis. Diagnosis tersebut dinyatakan sebagai infark miocard acut (IMA), unstable angina pectoris (OAP), dan Angina Pectoris (AP). Kasus adalah penderita PJK yang meninggal yang diambil dari Indeks Mortalitas selama tahun 2004 yang berjumlah 130 pasien. Penarikan sampel untuk kontrol dilakukan dengan cara systematic random sampling, perbandingan jumlah kasus kontrol adalah 1:2 (130 kasus : 260 kontrol).

Variabel independen yang diamati pada penelitian ini meliputi variabel kovariat dan variabel independen. Variabel kovariat meliputi umur, jenis kelamin, pendidikan dan pekerjaan yang diukur dalam skala nominal dan ordinal. Khusus untuk variabel umur digunakan usia $\geq 65$ tahun sebagai faktor prognosis, karena kematian meningkap paling tinggi pada usia tersebut. ${ }^{3}$ Variabel independen yang diamati meliputi jaminan pembayaran dan asal daerah/ kawasan, dan penyakit penyerta meliputi hipertensi, diabetes melitus, dislipidemia, dan riwayat pengobatan sebelumnya. Pengumpulan data dilakukan dengan mencatat hasil rekam medik, dengan menggunakan formulir pengumpulan data yang dibuat untuk penelitian ini. Analisis data dilakukan dengan menggunakan program komputer, data di analisis secara univariat dan multivariat dengan regresi logistik untuk mempelajari hubungan antara satu atau beberapa variabel independen dengan variabel dependen dengan dua kategori.

\section{Hasil}

\section{Distribusi kasus dan kontrol}

Jumlah sampel dalam penelitian ini adalah 390 orang yang terdiri dari 130 kasus dan 260 kontrol. Gambaran distribusi kasus dan kontrol (tabel 1), dari tabel ini dapat dilihat distribusi umur, jenis kelamin, jaminan pembayaran, asal daerah/ kawasan dan penyakit penyerta dislipidemia merupakan variabel yang potensial menjadi perancu. Proporsi responden berdasarkan umur, pasien yang berumur $>65$ tahun untuk kelompok kasus lebih tinggi yaitu 41,5\% dibandingkan dengan kelompok kontrol 18,5\%. Pasien dengan jenis kelamin laki-laki pa- 
da kelompok kasus 78,5\% lebih tinggi dibandingkan perempuan yang hanya $21,5 \%$. Proporsi kasus dan kontrol berdasarkan pendidikan pasien relatif tidak berbeda, demikian pula dengan pekerjaan pasien.

Proporsi pasien dengan jaminan pembayaran pribadi lebih tinggi pada kelompok kasus yaitu 48,5\% dibandingkan kontrol $(32,7 \%)$. Proporsi pasien yang berasal dari Jawa juga lebih tinggi pada kelompok kasus $(67,7 \%)$ dibandingkan kontrol $(51,2 \%)$. Proporsi pasien untuk penyakit penyerta hipertensi, diabetes melitus, dan riwayat PJK sebelumnya relatif tidak berbeda antara kasus dan kontrol, sedangkan untuk penyakit penyerta dislipidemia, proporsi kasus dan kontrol sedikit berbeda.

\section{Analisis Bivariat}

Analisis bivariat dilakukan untuk mengetahui variabel kandidat yang akan masuk ke dalam analisis multivariat. Bila hasil uji didapatkan nilai $p<0,25$ maka variabel tersebut dapat dimasukkan dalam model multivariat. Variabel yang masuk ke dalam model selain yang mempunyai nilai $\mathrm{p}<0,25$ juga mempertimbangkan adanya kemaknaan secara substansi.

Dari 10 variabel yang diperkirakan berhubungan de- ngan terjadinya kematian pasien penyakit jantung koroner hanya 5 (lima) variabel yang masuk sebagai kandidat multivariat masing-masing adalah 2 (dua) faktor karakteristik yaitu variabel umur $(p=0,000)$ dan jenis kelamin $(\mathrm{p}=0,090)$, sedangkan 3 (tiga) lainnya adalah faktor prognosis yaitu: jaminan pembayaran $(p=0,003)$, asal dae$\mathrm{rah} /$ kawasan $(\mathrm{p}=0,002)$ dan dislipidemia $(0,175)$. Masing-masing variabel tersebut mempunyai nilai $p<0,25$.

\section{Analisis Multivariat}

Analisis multivariat dengan regresi logistik untuk mengetahui efek murni pengaruh variabel independen terhadap terjadinya kematian pasien PJK dengan melihat hubungan faktor prognosis secara bersamaan. Adapun langkah-langkah yang dilakukan dalam analisis multivariat antara lain: pembuatan model secara lengkap dan melakukan model akhir, dengan hasil yang dapat dilihat pada tabel 3 dan tabel 4 .

Pemodelan lengkap dilakukan dengan memasukkan semua variabel independen yang telah lolos sensor ke dalam model. Tujuan dilakukan analisis ini adalah untuk mengetahui secara valid hubungan antara seluruh variabel prognosis dengan terjadinya kematian pasien penya-

Tabel 1: Distribusi kasus dan kontrol pasien PJK

\begin{tabular}{|c|c|c|c|c|}
\hline \multirow[t]{2}{*}{ Variabel } & \multicolumn{2}{|c|}{ Kasus } & \multicolumn{2}{|c|}{ Kontrol } \\
\hline & $\mathbf{N}$ & $\%$ & $\mathbf{N}$ & $\%$ \\
\hline \multicolumn{5}{|l|}{ Umur } \\
\hline$>65$ tahun & 54 & 41,5 & 48 & 18,5 \\
\hline$\leq 65$ tahun & 76 & 58,5 & 212 & 81,5 \\
\hline \multicolumn{5}{|l|}{ Jenis kelamin } \\
\hline Laki-laki & 102 & 78,5 & 222 & 85,4 \\
\hline Perempuan & 28 & 21,5 & 38 & 14,6 \\
\hline \multicolumn{5}{|l|}{ Pendidikan } \\
\hline Rendah & 48 & 36,9 & 83 & 31,9 \\
\hline Tinggi & 82 & 63,1 & 177 & 68,1 \\
\hline \multicolumn{5}{|l|}{ Pekerjaan } \\
\hline Tidak bekerja & 22 & 16,9 & 34 & 13,1 \\
\hline Bekerja tidak terikat & 14 & 10,8 & 41 & 15,8 \\
\hline Bekerja terikat & 94 & 72,3 & 185 & 71,2 \\
\hline \multicolumn{5}{|l|}{ Jaminan pembayaran } \\
\hline Pribadi & 63 & 48,5 & 85 & 32,7 \\
\hline Askes & 67 & 51,5 & 175 & 67,3 \\
\hline \multicolumn{5}{|l|}{ Asal daerah/ kawasan } \\
\hline Jawa & 88 & 67,7 & 133 & 51,2 \\
\hline Luar Jawa & 42 & 32,3 & 127 & 48,8 \\
\hline \multicolumn{5}{|c|}{ Penyakit penyerta hipertensi } \\
\hline Ya & 68 & 52,3 & 149 & 57,3 \\
\hline Tidak & 62 & 47,7 & 111 & 42,7 \\
\hline \multicolumn{5}{|c|}{ Penyakit penyerta diabetes mellitus } \\
\hline Ya & 55 & 42,3 & 105 & 40,4 \\
\hline Tidak & 75 & 57,7 & 155 & 59,6 \\
\hline \multicolumn{5}{|c|}{ Penyakit penyerta dislipidemia } \\
\hline Ya & 40 & 30,8 & 98 & 37,7 \\
\hline Tidak & 90 & 69,2 & 162 & 62,3 \\
\hline \multicolumn{5}{|c|}{ Riwayat PJK sebelumnya } \\
\hline Ya & 27 & 20,8 & 58 & 22,3 \\
\hline Tidak & 103 & 79,2 & 202 & 77,7 \\
\hline
\end{tabular}

Ket : $N$ = jumlah sampel 
Tabel 2. Analisis Bivariat untuk Seleksi Kandidat Multivariat

\begin{tabular}{lllll}
\hline Variabel & $\begin{array}{c}\mathbf{- 2} \text { Log } \\
\text { Likelihood }\end{array}$ & G & Nilai $\mathbf{p}$ & Ket \\
& $\mathbf{4 7 3 , 4 5 0}$ & $\mathbf{2 3 , 0 3 1}$ & $\mathbf{0 , 0 0 0}$ & $\mathbf{p}<\mathbf{0 , 2 5}$ \\
Umur & $\mathbf{4 9 3 , 6 1 3}$ & $\mathbf{2 , 8 6 8}$ & $\mathbf{0 , 0 9 0}$ & $\mathbf{p}<\mathbf{0 , 2 5}$ \\
Jenis kelamin & 495,979 & 0,502 & 0,479 & $\mathrm{p}>0,25$ \\
Pendidikan & 496,364 & 0,117 & 0,732 & $\mathrm{p}>0,25$ \\
Pekerjaan & $\mathbf{4 8 7 , 4 3 1}$ & $\mathbf{9 , 0 5 0}$ & $\mathbf{0 , 0 0 3}$ & $\mathbf{p}<\mathbf{0 , 2 5}$ \\
Jaminan pembayaran & $\mathbf{4 8 6 , 6 6 2}$ & $\mathbf{9 , 8 1 9}$ & $\mathbf{0 , 0 0 2}$ & $\mathbf{p}<\mathbf{0 , 2 5}$ \\
Asal daerah/ kawasan & 495,605 & 0,876 & 0,349 & $\mathrm{p}>0,25$ \\
Hipertensi & 496,349 & 0,132 & 0,716 & $\mathrm{p}>0,25$ \\
Diabetes melitus & $\mathbf{4 9 4 , 6 4 3}$ & $\mathbf{1 , 8 3 8}$ & $\mathbf{0 , 1 7 5}$ & $\mathbf{p}<\mathbf{0 , 2 5}$ \\
Dislipidemia & 496,360 & 0,121 & 0,728 & $\mathrm{p}>0,25$ \\
Riwayat PJK sebelumnya & & & & \\
\hline
\end{tabular}

Tabel 3. Analisis Regresi Logistik Multivariat

\begin{tabular}{|c|c|c|c|c|}
\hline Variabel & $\beta$ & Nilai P & OR & $\mathbf{9 5} \% \mathrm{CI}$ \\
\hline Jaminan & 0,514 & 0,026 & 1,67 & $1.06,2.63$ \\
\hline Asal daerah/ kawasan & 0,740 & 0,002 & 2,09 & $1.34,3.34$ \\
\hline Dislipidemia & 0,338 & 0,166 & 1,40 & $0.87,2.26$ \\
\hline Umur & 1,125 & 0,000 & 3,08 & $1.89,5.02$ \\
\hline Jenis kelamin & 0,301 & 0,303 & 1,35 & $0.76,2.40$ \\
\hline Constant & $-1,073$ & & & \\
\hline
\end{tabular}

Tabel 4. Model Regresi Logistik Multivariat Akhir

\begin{tabular}{|c|c|c|c|c|}
\hline Variabel & $\beta$ & Nilai $\mathbf{P}$ & OR & 95\% CI \\
\hline Jaminan & 0,510 & 0,027 & 1,67 & $1.06,2.62$ \\
\hline Asal daerah / kawasan & 0,748 & 0,002 & 2,11 & $1.33,3.36$ \\
\hline Dislipidemia & 0,361 & 0,136 & 1,44 & $0.89,2.31$ \\
\hline Umur & 1,150 & 0,000 & 3,16 & $1,94,5.13$ \\
\hline Constant & $-0,852$ & & & \\
\hline
\end{tabular}

-2 Log Likelihood $=455,078$

kit jantung koroner dengan mengontrol variabel kovariat (umur dan jenis kelamin). Dari hasil analisis secara bersama-sama variabel prognosis (jaminan, asal dae$\mathrm{rah} /$ kawasan, dislipidemia) dengan di kontrol variabel kovariat (umur dan jenis kelamin) terlihat bahwa variabel jenis kelamin mempunyai nilai pWald $>0,05$ sehingga dikeluarkan dari model.

Dari keseluruhan proses analisis yang telah dilakukan dan dengan mempertimbangkan kemaknaan secara substansi, maka didapatkan hasil pada model akhir bahwa dari 6 (enam) variabel independen yang diduga berhubungan dengan kematian pasien penyakit jantung koroner, ternyata hanya 3 (tiga) yang berhubungan secara statistik bermakna setelah variabel lain dikendalikan (tabel 4): Jaminan pembayaran dengan nilai $\mathrm{OR}=1,67$ (95\% CI: 1.06, 2.62) yang berarti bahwa pasien dengan jaminan pembayaran pribadi berisiko untuk meninggal 1,67 kali lebih besar daripada pasien dengan jaminan pembayaran Askes setelah dikontrol variabel lain. Asal daerah/kawasan OR=2,11 (95\% CI: 1.33, 3.36), berarti pasien yang berasal dari Jawa berisiko untuk meninggal 2,11 kali dibandingkan dengan pasien yang berasal dari luar Jawa. Dislipidemia OR=1,44 (95\% CI: 0.89, 2.31), artinya pasien dengan penyakit penyerta dislipidemia berisiko untuk meninggal 1,44 kali dibandingkan dengan pasien yang tidak mempunyai penyakit penyerta dislipidemia. Umur merupakan variabel kovariat yang berpengaruh terhadap hubungan variabel independen dengan variabel dependen, $\mathrm{OR}=3,16$ (95\% CI 1.94, 5.13). Pasien yang berumur $>65$ tahun berisiko untuk meninggal 3,16 kali dibandingkan pasien yang berumur $\leq 65$ tahun.

\section{Pembahasan}

Salah satu keterbatasan penelitian ini adalah tidak dilihat dan diuraikan lebih rinci tentang diagnosis dan tingkat keparahan penyakit jantung koroner yang diderita oleh setiap pasien yang berhubungan dengan jenis tindakan yang dilakukan, sehingga sangat mempengaruhi prognosis. Untuk itu perlu dilakukan penelitian lebih lanjut yang melihat kematian pasien PJK dengan memperhatikan jenis diagnosis dan tingkat keparahan penyakit yang berpengaruh terhadap jenis tindakan yang dilakukan serta prognosis. ${ }^{4}$

Jaminan pembayaran berhubungan dengan kematian pasien PJK, pasien dengan jaminan pembayaran pribadi berisiko untuk meninggal 1,67 kali lebih besar daripada pasien dengan jaminan pembayaran asuransi. Hasil penelitian yang dilakukan oleh Heller ${ }^{5}$ mengenai manajemen angina tidak stabil di rumah sakit Australia dengan salah satu variabelnya adalah klasifikasi asuransi mendapatkan hasil bahwa terdapat hubungan antara status asuransi dengan pemilihan jenis tindakan oleh pasien penyakit jantung koroner. Pasien bebas menentukan jenis tindakan dan pengobatan yang dibutuhkan segera, kemungkinan karena ada jaminan pembayaran dari pihak asuransi.

Asuransi Kesehatan (Askes) mempunyai berbagai macam manfaat seperti yang dikemukakan oleh Rieger \& Miller (1989) dalam Insurance Principles \& Practice yaitu memberikan rasa aman bagi pasien dan keluarganya. Askes dapat memberikan perlindungan terhadap berbagai risiko berupa kompensasi atau penggantian biaya perawatan dan tindakan medis yang dibutuhkan. Dengan demikian, menurunkan risiko ekonomi peserta asuransi yang sakit. Jaminan pelayanan kesehatan tersebut akan mengurangi kekhawatiran atau kecemasan (anxiety). Mekanisme hubungan antara jaminan pembayaran dengan terjadinya kematian pasien PJK bermula dari timbulnya kecemasan pada pasien, khususnya pada pasien yang kurang mampu dan dengan jaminan pembayaran pribadi. Kecemasan pada pasien PJK menghasilkan reaksi fisiologis seperti meningkatnya tekanan darah dan denyut jantung yang semakin cepat sehingga dapat memperberat penyakitnya dan menimbulkan komplikasi yang bisa menyebabkan kematian.6,7 Pasien tanpa asuransi, 
kemungkinan untuk terlambat dibawa ke rumah sakit atau fasilitas pelayanan kesehatan dapat terjadi dengan alasan ketidakmampuan pasien dan keluarga untuk mengadakan biaya sesegera mungkin saat dibutuhkan. Dengan demikian, pasien di bawa ke fasilitas pelayanan kesehatan atau rumah sakit ketika penyakit telah semakin parah. Akibatnya, penderita terlambat mendapat perawatan memadai, sehingga terjadi berbagai komplikasi yang menyebabkan kematiannya.

Asal daerah/kawasan berhubungan dengan terjadinya kematian pasien PJK, pasien yang berasal dari daerah/kawasan Jawa berisiko untuk terjadinya kematian sebesar 2,11 kali dibandingkan dengan pasien berasal dari daerah/kawasan luar Jawa. Hubungan asal daerah/ kawasan dengan kematian PJK melalui mekanisme antara pengaruh lingkungan pemukiman, kondisi kerja termasuk stres kerja, pola makan populasi yang berbeda dan kemudahan akses fasilitas pelayanan kesehatan. Penelitian yang dilakukan oleh Hunt, ${ }^{8}$ dengan desain studi kohort tahun 1979-1988 yang melihat hubungan antara etnis (Mexico Amerika dan kulit putih nonHispanik) dengan kematian karena berbagai sebab dan kematian akibat kardiovaskuler didapatkan hasil bahwa terdapat perbedaan jumlah kematian antara kedua etnik, hal ini disebabkan oleh adanya perbedaan prevalens penyakit jantung koroner akibat berbedanya riwayat profil lipid dan adanya perbedaan jumlah faktor risiko penyakit jantung koroner yang ditemukan antara kedua etnis. Hal ini didukung oleh proyek surveilans berbasis masyarakat (The Corpus Christi Heart Project) yang melaporkan tingginya insiden penyakit jantung koroner di rumah sakit, tingginya fatality rate PJK dan tingginya angka kematian PJK yang terjadi baik di dalam maupun di luar rumah sakit pada etnis Mexico Amerika dibandingkan dengan kulit putih non Hispanik.

Hipertensi meningkatkan beban jantung yang akan membuat dinding jantung menebal, jantung makin lama makin membesar dan melemah, hal ini akan meningkatkan serangan jantung dan gagal jantung kongestif. Apabila terjadi tekanan terus menerus pada pembuluh darah, jantung terpaksa bekerja keras untuk mengimbanginya, desakan terus menerus dari tekanan darah bilik kiri ventrikel yang memompakan darah ke aorta menjadi lemah dan membengkak yang mengakibatkan jantung tidak dapat memompakan darah secara maksimal ke seluruh tubuh. Lambat laun akan terjadi kegagalan jantung yang ditandai oleh berbagai gejala dan salah satu diantaranya sesak nafas yang pada mulanya terjadi pada malam hari pada saat orang berbaring dan kemudian terjadi pada sembarang waktu. ${ }^{9}$

Penyakit penyerta hipertensi dalam penelitian ini tidak berhubungan dengan terjadinya kematian pasien PJK. Kemungkinan hal ini disebabkan oleh kelompok kasus dan kontrol yang homogen. Hasil penelitian yang dilakukan oleh Anastasia ${ }^{10}$ didapatkan bahwa hipertensi pada penderita penyakit jantung koroner kurang berisiko untuk terjadi kematian. Penelitian yang dilakukan Budiningrum, ${ }^{11}$ menemukankan tidak ada perbedaan kematian yang bermakna antara penderita infark miokard akut (IMA) yang hipertensi dan yang tidak hipertensi. Penelitian ini tidak memperlihatkan hubungan yang bermakna antara hipertensi dengan kematian pasien penyakit jantung koroner. Hal tersebut kemungkinan disebabkan oleh pemberian obat antihipertensi yang tepat sehingga terkendali. Hal ini sesuai dengan yang hasil penelitian The Treatment of Mild Hypertension Study (TOMH Study) yang mengemukakan bahwa pemberian obat antihipertensi berpengaruh menurunkan morbiditas dan mortalitas kardiovaskuler. Sedangkan kombinasi antara obat antihipertensi dengan perubahan gaya hidup menurunkan morbiditas dan mortalitas kardiovaskuler lebih banyak. 12

Kematian penyakit jantung pada pasien tanpa diabetes dengan tekanan darah tinggi sekitar 140-159 mmHg adalah sekitar $2,2 \%$, tetapi pada kelompok pasien dengan diabetes melitus dengan tekanan darah sistolik yang sama mempunyai risiko kematian karena kardiovaskuler lebih tinggi yaitu 5,3\%. Diabetes Melitus yang timbul pada usia dewasa sering mengalami penyakit arteri perifer, sehingga mengalami percepatan aterosklerosis. Sekitar $75-80 \%$ kematian penderita diabetes disebabkan macro angiopati terutama pada PJK. ${ }^{13}$

Pada pemilihan variabel kandidat multivariat, penyakit penyerta diabetes mellitus tidak berhubungan dengan terjadinya kematian pasien PJK. Hasil ini berbeda dengan hasil penelitian Anastasia ${ }^{10}$ di Pusat Jantung Nasional Harapan Kita. Didapatkan bahwa kematian penderita PJK yang menderita diabetes melitus berhubungan bermakna. Penderita PJK yang menderita diabetes mellitus berisiko 2,37 kali untuk meninggal daripada yang tidak menderita PJK. Penelitian oleh Apitule ${ }^{14}$ melaporkan hubungan yang bermakna antara diabetes mellitus dengan kematian PJK di rumah sakit. Perbedaan antara tersebut kemungkinan disebabkan oleh perbedaan jumlah sampel dan desain penelitian. Pengendalian diabetes mellitus akan mengurangi risiko komplikasi lanjut DM pada penderita penyakit jantung koroner. Oleh sebab itu, penderita diabetes mellitus disarankan untuk memperhatikan pola makan dan aktifitas fisik sehari-hari. Makanan yang dianjurkan adalah yang seimbang komposisi energi dari karbohidrat, protein dan lemak. Anjuran makan seimbang tersebut sama seperti anjuran makan sehat pada umumnya, tidak ada makanan yang dilarang, hanya dibatasi sesuai kebutuhan/tidak berlebihan). Sedangkan latihan fisik diperlukan untuk menurunkan kadar glukosa darah (mengurangi resistensi insulin, meningkatkan sensitifitas insulin), menurunkan berat badan, mengurangi kemungkinan komplikasi aterogenis, gangguan lipid darah, 
peningkatan tekanan darah dan hiperkoagulasi darah. ${ }^{15}$

Pada penyaringan variabel kandidat multivariat, dislipidemia masuk dalam model multivariat atas pertimbangan kemaknaan substansi. Namun pada analisis multivariat ternyata dislipidemia tidak berhubungan dengan kematian pasien PJK. Hasil penelitian ini berbeda dengan penelitian yang dilakukan oleh Shekele, dkk di Amerika yang mengamati 1900 orang berumur 40-45 tahun selama 20 tahun. Penelitian tersebut menemukan korelasi positif antara kematian PJK dengan asupan kolesterol/ dislipidemia. Semakin tinggi kadar kolesterol semakin tinggi pula kematian akibat penyakit kardiovaskuler. ${ }^{13}$ Perbedaan hasil penelitian ini dengan penelitian Shekele tersebut, mungkin disebabkan oleh perbedaan dalam desain penelitian yang menggunakan data pengamatan selama 20 tahun dengan jumlah sampel yang lebih besar. Dislipidemia dianggap berperan sama penting atau bahkan lebih penting daripada faktor risiko kardiovaskuler yang lain. Studi epidemiologi membuktikan hubungan antara peningkatan kadar kolesterol total, khususnya low-density lipoprotein cholesterol (LDL-C) dengan angka kejadian kesakitan dan kematian penyakit jantung koroner. Untuk mengatasi masalah PKV khususnya PJK, The US National Cholesterol Education Program (NCEP)/ Adult Treatment Panel (ATP) III 2001 telah merekomendasikan penurunan kadar LDL-C sebagai sasaran primer dalam mengatasi masalah sindrom metabolik (antara lain HDL-C dan trigliserida) sebagai sasaran sekunder, dengan tetap memperhatikan modifikasi gaya hidup ke arah yang lebih sehat. ${ }^{16}$

Penelitian ini menemukan bahwa riwayat PJK sebelumnya, tidak berhubungan dengan kematian PJK. Hasil tersebut berbeda dengan beberapa penelitian sebelumnya yang mendapatkan bahwa orang dengan riwayat penyakit jantung koroner sebelumnya mempunyai risiko $5 x$ lebih besar untuk meninggal pada 5 (lima) tahun pertama dibandingkan dengan yang tidak mempunyai riwayat PJK sebelumnya. ${ }^{17}$ Perbedaan ini kemungkinan disebabkan oleh jumlah sampel yang kurang. Pasien penyakit jantung koroner yang pernah mengalami serangan jantung sebelumnya kemungkinan tidak berobat di Pusat Jantung Nasional Harapan Kita yang tidak dikemukakan pada dokter yang terakhir merawat pasien atau adanya kesalahan diagnosis. Kemungkinan lain adalah ketidaktahuan pasien pada gejala serangan jantung pada saat serangan pertama, sehingga pasien tetap tercatat sebagai pasien baru PJK. Serangan PJK yang berulang dapat dihindari dengan mengubah gaya hidup risiko tinggi. Jika upaya tersebut telah dilakukan, intervensi farmakologis dengan pemilihan obat yang tepat dan kedisiplinan pasien mengkonsumsi obat sangat diperlukan. Namun, upaya tersebut harus tetap dilanjutkan untuk menghindari terjadinya serangan jantung yang berulang.
Untuk variabel kovariat, hanya variabel umur yang berpengaruh secara bermakna terhadap hubungan antara variabel independen dengan variabel dependen. Pasien yang berumur $>65$ tahun berisiko untuk meninggal sebesar 3,16 kali dibandingkan dengan pasien yang berumur $\leq 65$ tahun. Penelitian yang dilakukan di Amerika didapatkan bahwa umur sangat berhubungan dengan kematian akibat penyakit jantung, dimana empat dari lima orang yang meninggal akibat serangan jantung berumur lebih dari 65 tahun. Sedangkan penelitian terhadap kematian jemaah haji akibat penyakit kardiovaskuler, didapatkan hasil $73,5 \%$ jemaah haji yang meninggal dunia berumur 60 tahun ke atas. ${ }^{18}$

Peningkatan usia akan meningkatkan kemungkinan terjadinya kematian PJK. Peningkatan usia menyebabkan perubahan anatomi dan fisiologik pada jantung manusia. Perubahan anatomi meliputi perubahan dinding media aorta, penurunan jumlah inti sel jaringan $f i$ brosa stroma katup, penumpukan lipid, perubahan miokardium akibat proses penuaan yang klasik berupa "brown atrophy", penurunan berat jantung dan timbulnya lesi fibrotik diantara serat miokardium. Sedangkan perubahan fisiologik jantung berupa denyut jantung maksimum latihan menurun, isi semenit jantung (cardiac output) dan daya cadangan jantung menurun. Sifat penyakit jantung pada golongan usia lanjut umumnya patologi multiple, gejala dan tanda tersembunyi, occult, tidak khas, atipik, bervariasi aneka ragam, sering pula asimptomatik, progresif dan sering bersifat kronik sehingga menimbulkan invaliditas yang cukup lama sebelum akhirnya meninggal. ${ }^{19}$

\section{Kesimpulan}

Faktor-faktor yang berhubungan dengan kematian pasien penyakit jantung koroner setelah dikendalikan dengan variabel umur adalah jaminan pembayaran. Pasien dengan jaminan pembayaran pribadi lebih berisiko untuk terjadinya kematian dibandingkan pasien dengan jaminan pembayaran Askes. Asal daerah/ kawasan, pasien yang berasal dari Jawa lebih berisiko untuk terjadinya kematian dibandingkan dengan pasien yang berasal dari luar Jawa.

\section{Saran}

1. Kepada masyarakat

Masyarakat disarankan untuk mendapatkan pelayanan kesehatan yang optimal dan sesegera mungkin. Juga disarankan untuk menjadi peserta asuransi kesehatan atau berbagai bentuk jaminan pemeliharaan kesehatan lain. Bagi penderita penyakit jantung koroner dan keluarganya (kelompok risiko tinggi) disarankan untuk berkonsultasi dengan dokter ahli jantung untuk mengetahui perkembangan penyakitnya sedini mungkin sehingga komplikasi lanjut yang menyebabkan ke- 
matian dapat dicegah.

2. Kepada Pusat Jantung Nasional Harapan Kita. Penyuluhan tentang pentingnya keikutsertaan pasien dan keluarganya (kelompok risiko tinggi) dalam asuransi kesehatan perlu selalu dilakukan untuk mencegah keterlambatan pasien dibawa ke rumah sakit akibat ketiadaan biaya berobat. Pasien penyakit jantung koroner yang berusia lanjut atau berumur $>$ 65 tahun memerlukan penanganan khusus.

3. Kepada para peneliti kematian pasien penyakit jantung koroner

Berdasar hasil penelitian ini disarankan untuk melakukan penelitian berikut: Pertama, menilai secara lebih spesifik mekanisme hubungan jaminan pembayaran dengan kematian pasien PJK, yang meliputi perbedaan pelayanan, faktor pekerjaan, keterlambatan ke rumah sakit dan stres. Kedua, penelitian insiden kematian pada populasi yang luas secara lebih selektif terhadap faktor asal daerah/ kawasan berdasarkan suku dan penyakit penyerta. Ketiga, berbagai penelitian tersebut perlu secara lebih cermat mengendalikan pengaruh diagnosis dan tingkat keparahan penyakit terhadap kematian akibat penyakit jantung koroner.

\section{Daftar Pustaka}

1. Sani, Aulia. Penyakit Kardiovaskuler, Pembunuh Nomor Wahid, www.kompas.com, Diakses tanggal 5 Februari 2005 jam19.54; 2000

2. Departemen Kesehatan Republik Indonesia. Survei Kesehatan Nasional 2001: Laporan Studi Mortalitas 2001: Pola Penyakit Penyebab Kematian di Indonesia, Badan Penelitan dan Pengembangan Kesehatan, Jakarta; 2002; 76 hlm

3. Bronson, Ross C st all, 1993, Chronic Diseaser Epidemiology and Control, American Public Health Association.

4. Kusmana, Dede. 2003. Standar Pelayanan Medik RS Jantung \& Pembuluh Darah Harapan Kita, Pusat Jantung Nasional Harapan Kita, Jakarta.
5. Heller, R.F. 2001. Trends in the hospital management of unstable angina. Journal Epidemiol Community Health: 483-486

6. Julian, Desmond \& Claire Marley, Coronary Heart Disease the Facts, Oxford University Press, New York; 1991; $120 \mathrm{hlm}$

7. American Heart Association, Guide to Heart Attack: Treatment, Recovery and Prevention, Times Books, Random House, USA; 1996 ; $300 \mathrm{hlm}$

8. Hunt, Kelly J. 2003. All cause and cardiovascular mortality among mexican - american \& non. Hispanic white older participants in the san antonio hearth study evidence againts the "hispanic paradox". American Journal Epidemiology: Hlm: 1048 - 1057

9. Hull, Alison, Penyakit Jantung, Hipertensi dan Nutrisi. terjemahan. Dr. Wendra Ali, Bumi Aksara, Jakarta; 1996; 85 hlm

10. Anastasia, Hayani. Faktor prognosis kematian pasien rawat inap penyakit jantung koroner di Rumah Sakit Jantung Harapan Kita, Jakarta, tahun 1999 - 2000. Skripsi. FKM UI, 2002

11. Budiningrum, Asih. 1998. Faktor-faktor yang berhubungan dengan kematian pada penderita infark miokard akut yang dirawat di ICCU RSUPN Dr. Cipto Mangunkusumo Jakart tahun 1990 - 1994. Skripsi FKM UI: xi +48 hlm.

12. Bustan, M, N., Epidemiologi Penyakit Tidak Menular, Rineka Cipta, Jakarta; $2000 ; 134 \mathrm{hlm}$

13. Supari, Fadilah, Konsep Baru Pencegahan Penyakit Jantung Koroner, Majalah Kedokteran Masyarakat Indonesia, XXVII (4), Jakarta ; 1999 ; hlm 218-222

14. Apitule D. 1997. Beberapa faktor yang berkaitan dengan kematian di Rumah Sakit pada wanita dengan dengan infark miokard akut. Kardiologi Indonesia: XXII (2): hlm $72-82$.

15. PERKENI, Petunjuk Praktis Pengelolaan Diabetes Mellitus Tipe II, Jakarta ; $2003 ; 52$ hlm

16. Subekti, Imam, Pengelolaan Dislipidemia pada Tingkat Pelayanan Primer, Majalah Kedokteran Indonesia, Jakarta ; 2005 ; 55(3): hlm 285290

17. Kodim, Nasrin. 1992. Himpunan bahan kuliah epidemiologi penyakit tidak menular. Jurusan Epidemiologi FKM UI: $168 \mathrm{hlm}$.

18. Muchtar, Muhammad, Pengaruh Penyakit Kardiovaskuler Terhadap Kematian Jemaah Haji Asal Jawa Barat Embarkasi Halim Perdana Kusumah, Tesis FKM UI ; 1998 ; 94 hlm

19. Darmojo, R. Boedhi. Kelainan Kardiovaskuler pada usia lanjut dalam: Bunga Rampai Karangan Ilmiah Prof. R. Boedhi Darmojo, Buku II Kardiovaskuler, Bagian/UPF Ilmu Penyakit Dalam FK Undip/RS Dr. Karyadi, Semarang, 1994. 